\title{
Effect of preheating on cytotoxicity and physicochemical properties of light-cured calcium-based cements
}

\author{
Diana LB Borghetti', Roberto Zimmer ${ }^{1}$, Fernando F Portella², Eduardo G Reston', Celso A \\ Klein-Junior', Daniel R Marinowic ${ }^{3}$, Keiichi Hosaka ${ }^{4}$ \\ 1 Universidade Luterana do Brasil, Departamento de Dentística, Canoas, Rio Grande do Sul, Brasil. \\ 2 Universidade Feevale, Instituto de Ciências da Saúde, Novo Hamburgo, Rio Grande do Sul, Brasil. \\ 3 Pontifícia Universidade Católica do Rio Grande do Sul, Instituto do Cérebro, Porto Alegre, Rio Grande do Sul, Brasil. \\ ${ }^{4}$ Tokyo Medical and Dental University, Department of Oral Health Science, School of Medical and Dental Science, Tokyo, \\ Japan.
}

\begin{abstract}
The aim of this study was to evaluate the degree of conversion, cytotoxicity, solubility and $\mathrm{pH}$ of photopolymerizable calciumbased cements submitted to preheating. The degree of conversion was analyzed by Fourier transform infrared, cytotoxicity by the MTT test and solubility through loss of mass. The data were subjected to statistical tests (ANOVA / Tukey's, $\mathrm{p}<0.05)$. The photopolymerizable materials showed a low degree of conversion, regardless of preheating. All materials caused a reduction in cell viability at 24 hours and 7 days, with the Dycal
\end{abstract}

(control) being more cytotoxic. Heat had a positive effect on Biocal at 7 days. Dycal is the most soluble material. Heat had no effect on the solubility or $\mathrm{pH}$ of the polymerizable materials. It is concluded that photopolymerizable calcium-based cements have a low degree of conversion and are soluble, which results in mild to moderate cytotoxicity.

Received: April 2020; Accepted: June 2020.

Keywords: dental pulp capping- dental cements-calcium hydroxide-polymerization-cell survival.

\section{Efeito do pré-aquecimento na citotoxicidade e propriedades físico-químicas de cimentos à base de cálcio fotopolimerizáveis}

\begin{abstract}
RESUMO
O objetivo do presente estudo foi avaliar o grau de conversão, citotoxicidade, solubilidade e $\mathrm{pH}$ de cimentos à base de cálcio fotopolimerizáveis submetidos a pré-aquecimento. O grau de conversão foi analisado por espectroscopia no infravermelho com transformada de Fourier, a citotoxicidade pelo teste de MTT e a solubilidade através da perda de massa. Os dados foram submetidos a testes estatísticos (ANOVA/Tukey, $p<0,05$ ). Os materiais fotopolimerizáveis apresentaram baixo grau de conversão, independente do pré-aquecimento. Todos os materiais causaram redução da viabilidade celular nas análises
\end{abstract}

\section{INTRODUCTION}

Deep and very deep cavities resulting from tooth decay or trauma often require protection of the dentin-pulp complex ${ }^{1}$. Calcium hydroxide has been the most intensively studied biomaterial over time and provided favorable clinical results ${ }^{2}$, although, according to a systematic review and meta-analysis, its use is reported as unnecessary in deep caries lesions in primary and permanent teeth and has questionable clinical success. Randomized, de 24 horas e 7 dias, sendo que o Dycal (controle) apresentouse mais citotóxico e o calor apresentou efeito positivo sobre o Biocal na análise de 7 dias. O Dycal é o material mais solúvel e o calor não causou efeito na solubilidade e $\mathrm{pH}$ dos materiais polimerizáveis. Assim, conclui-se que os cimentos à base de cálcio fotopolimerizáveis apresentam baixo grau de conversão e são solúveis, que resulta em citotoxicidade suave e moderada.

Palavras-chave: capeadores pulpares- cimentos dentárioshidróxido de cálcio- polimerização-sobrevivência celular.

controlled clinical trials are still needed to provide strong recommendations on the actual need for use of calcium hydroxide ${ }^{3}$.

Calcium hydroxide remains the most commonly used pulp protection material due to its alkalinity, biocompatibility, ability to decrease bacterial infection and induce pulp tissue to form a mineralized barrier, blocking the exposed surface ${ }^{1,2,4}$. However, it has some limitations, such as high solubility, poor bonding to dentin and mechanical instability ${ }^{5}$. 
Photopolymerizable protective materials are useful because they provide greater mechanical resistance, better handling, more precise application, are minimally affected by phosphoric acid and have better marginal sealing due to their lower solubility ${ }^{6,7}$. However, they have incomplete polymerization, with monomers remaining free $^{7}$, which can cause toxic reactions to the pulp cells ${ }^{8}$. The biocompatibility and cytotoxicity of pulp protection materials is of paramount importance in preventing or limiting irritation to the pulp, and they have been widely studied in different cell cultures or in deep cavities, with or without pulp exposure9 . The degree of conversion (DC) of the monomers is a measure of the percentage of carbon double bonds that have been converted to single carbon bonds to form a polymer chain resulting from the polymerization process. On average, $70 \%$ of the monomers are converted into polymers and $30 \%$ are not polymerized, with the majority of these unconverted monomers remaining in the polymer matrix, while $9 \%$ of them remain free and are able to diffuse through the dentinal tubules and reach the pulp ${ }^{7}$.

Some techniques to improve polymerization have been researched and it is known that preheating resin composites increases their conversion. A study by Daronch et al. (2005) used a device that heats composite resin before use, which increased monomer conversion without increasing intrapulp temperature when compared to composites placed at room temperature, showing that the preheated composite can be used safely ${ }^{10}$. In order to increase the conversion of monomers, several studies have used different polymerization methods, reporting improvements in the physical and biological properties of heated resinous materials ${ }^{11-13}$.

Studies have shown that resinous materials are cytotoxic, with harmful effects on the pulp, but further studies are needed on the use of photopolymerizable calcium-based cements. Thus, our aim is to evaluate the degree of conversion, cytotoxicity, solubility and $\mathrm{pH}$ of photopolymerizable calcium-based cements and their effect when subjected to preheating.

\section{MATERIALS AND METHODS}

In the present study, four materials were used to protect the dentin-pulp complex, three based on calcium hydroxide: Dycal ${ }^{\circledR}$ (Dentsply Sirona, Milford, DE, USA), Biocal ${ }^{\circledR}$ (Biodynamics, Ibiporã, PR, Brazil) and Ultra-blend ${ }^{\circledR}$ plus (Ultradent
Products Inc., South Jordan, UT, USA), and one based on calcium silicate, TheraCal ${ }^{\circledR}$ LC (Bisco, Schaumburg, IL, USA).

Specimens were prepared at room temperature following the manufacturers' guidelines and photoactivated for $40 \mathrm{~s}$ using a device with a lightemitting diode (LED) with power adjustment at 1000 $\mathrm{mW} / \mathrm{cm}^{2}$ (VALO, Ultradent, Salt Lake City, Utah, USA). The same materials were also prepared with previous heating by placing the molds on a heated base at $39{ }^{\circ} \mathrm{C}$ in a HotSet ${ }^{\circledR}$ device (Technolife, Joinville, $\mathrm{SC}$, Brazil) for $1 \mathrm{~min}$, followed by photoactivation for $40 \mathrm{~s}$. After photoactivation, the specimens were removed from the molds and sterilized in ethylene oxide (Esteriliplus, Porto Alegre, RS, Brazil). Table 1 summarizes the experimental groups evaluated. The materials were subjected to the tests described below.

\section{Cell viability}

Specimens were prepared in a metallic mold $6 \mathrm{~mm}$ in diameter and $1 \mathrm{~mm}$ in depth $(\mathrm{n}=5)$ for the test, which was carried out according to ISO 10993-12: $2012^{14}$, in a similar way to that described by Portella et al. ${ }^{15}$ The cells used for the present study were mouse fibroblasts of the NIH 3 T3 strain (ATCC $®$ American Type Culture Collection - TCC, Old Town, Maryland, USA). Cell viability was assessed by analyzing mitochondrial activity using the methyl tetrazolium (MTT) technique. The percentage of unviable cells was calculated in relation to the negative control (cells cultured in DMEM medium).

\section{Degree of Conversion (DC)}

The DC was evaluated using the Fourier Transformed Infrared Spectroscopy (FTIR) technique. The spectrophotometer (VERTEX 70, Bruker Optics, Ettingen, Germany) was coupled to the ATR device, composed of a $2 \mathrm{~mm}$ horizontal diamond crystal (Platinum ATR-QL, Bruker Optics, Ettlingen, Germany), forming an angle of $45^{\circ}$ with mirror ${ }^{16}$. The samples $(n=3)$ were made from a standardized volume of material that was dispensed on the crystal of the attenuated total reflectance device (ATR), being retained within a cylindrical mold $5 \mathrm{~mm}$ in diameter by $1 \mathrm{~mm}$ in depth. In the groups where the materials were heated, the material compules were heated until they reached a temperature of $39^{\circ} \mathrm{C}$ using the HotSet ${ }^{\circledR}$ heating device. After being removed from the heating device, they were immediately dispensed in the mold and photoactivated for $40 \mathrm{~s}$. 
Table 1. Experimental groups and procedures used.

\begin{tabular}{|c|c|}
\hline GROUP & MATERIAL \\
\hline DYC & Dycal $\AA$ \\
\hline BIO & Biocal $\AA$ \\
\hline BIO $39^{\circ} \mathrm{C}$ & Biocal $\AA$ \\
\hline THE & TheraCal LC $\AA$ \\
\hline THE $39^{\circ} \mathrm{C}$ & TheraCal LC $\AA$ \\
\hline ULT & Ultra-Blend plus $\AA$ \\
\hline ULT $39^{\circ} \mathrm{C}$ & Ultra-Blend plus $\AA$ \\
\hline
\end{tabular}

\section{PROCEDURES}

Room temperature + Chemical activation

Room temperature + Photoactivation 40' $39{ }^{\circ} \mathrm{C}+$ Photoactivation 40 '

Room temperature + Photoactivation 40' $39 \stackrel{\circ}{ } \mathrm{C}+$ Photoactivation 40 '

Room temperature + Photoactivation 40' $39 \stackrel{\circ}{\circ}+$ Photoactivation $40^{\prime}$
The degree of conversion was determined from the ratio of the absorbance peak corresponding to the carbon-carbon aliphatic double bond $\left(1640 \mathrm{~cm}^{-1}\right)$ with that of the internal standard $\left(1610 \mathrm{~cm}^{-1}\right.$ for the Biocal ${ }^{\circledR}$ and TheraCal ${ }^{\circledR}$ LC materials and $1720 \mathrm{~cm}$ ${ }^{-1}$ for the Ultra-Blend ${ }^{\circledR}$ plus material). Percentage DC was calculated according to a previous study ${ }^{16}$.

\section{Solubility and pH}

Degradation was evaluated by weight loss (WL) of materials after immersing the samples in $10 \mathrm{~mL}$ of distilled water for $24 \mathrm{~h}$ and 7 days at $36^{\circ} \mathrm{C}$. The dry mass of the samples was determined before (W0) and after immersion (Wf). Average WL of the samples $(\mathrm{n}=3)$ was obtained using the equation:

$$
\mathrm{WL}(\%)=\left(\mathrm{W}_{\mathrm{f}}\right)-\left(\mathrm{W}_{0}\right) / \mathrm{W}_{0} \times 100
$$

A digital $\mathrm{pH}$ meter (pH meter DM-23, Digicrom Analytical Ltda, São Paulo, SP, Brazil) was used to measure the $\mathrm{pH}$ of the storage water after $24 \mathrm{~h}$ and 7 days. The initial $\mathrm{pH}$ of the water used for the immersion of the samples was $5.96 \pm 0.54$.

\section{Statistical Analysis}

The mean values determined for the experimental groups in the cytotoxicity, solubility and $\mathrm{pH}$ tests were compared using the two-way ANOVA test (experimental group and time), followed by the Tukey's test. For the DC test, two-way ANOVA (material and heating) and the Tukey's test were used. All analyses were performed with a 5\% significance level.

\section{RESULTS}

The results show that all cements, regardless of the treatment used in the present study (chemically activated polymerization, photoactivation and heating prior to photoactivation), according to ISO 10993-5: 2009 (E) ${ }^{17}$, presented mild to moderate cytotoxicity, demonstrated by the reduction in the number of viable cells when compared to the negative control group $(p<0.05)$ (Fig. 1). The chemically activated cement, on the other hand, presented severe cytotoxicity, statistically higher than in photopolymerizable calcium-based cements $(p<0.05)$. In the $24 \mathrm{~h}$ cell viability analyses, there was no statistical difference between the photopolymerizable calcium-based cements used and the preheating of the cements did not reduce their cytotoxicity. However, there is less significant cytotoxicity in light-cured calcium-based cements than in the negative control group and the DYC group. When the cell viability of 7 days was analyzed, the BIO $39^{\circ} \mathrm{C}$ group showed a significant decrease in the cytotoxicity of the material, and the preheating caused a positive effect on cell viability. On the other hand, the DYC was statistically more cytotoxic than the experimental groups. When comparing the $24 \mathrm{~h}$ and 7 day analyses, the BIO $39^{\circ} \mathrm{C}$ material showed a decrease in cytotoxicity over the extraction time of the material, while the THE and ULT materials showed a significant decrease in viability over time. The heat treatment did not result in a significant increase in the DC of the materials used. Fig. 2 shows that degree of conversion percentage for the THE material was extremely low both at room temperature $(12.65 \pm 10.31)$ and heated $(7.84 \pm$ 9.46). At room temperature, DC was significantly higher for ULT than for THE $(51.87 \pm 4.35 ; p<0.05)$, while BIO $(34.47 \pm 21.72)$ did not differ statistically from either of the other products. When the materials were heated, ULT $39^{\circ} \mathrm{C}(46.30 \pm 1.38)$ and $\mathrm{BIO} 39^{\circ} \mathrm{C}$ $(45.71 \pm 6.76)$ had significantly higher polymeric conversion $(p>0.05)$ than THE $39^{\circ} \mathrm{C}(7.84 \pm 9.46)$. All materials lost $0.04 \%$ to $17.68 \%$ of their mass (Table 2). DYC immersed in distilled water for 7 days had the highest solubility among all groups, with 


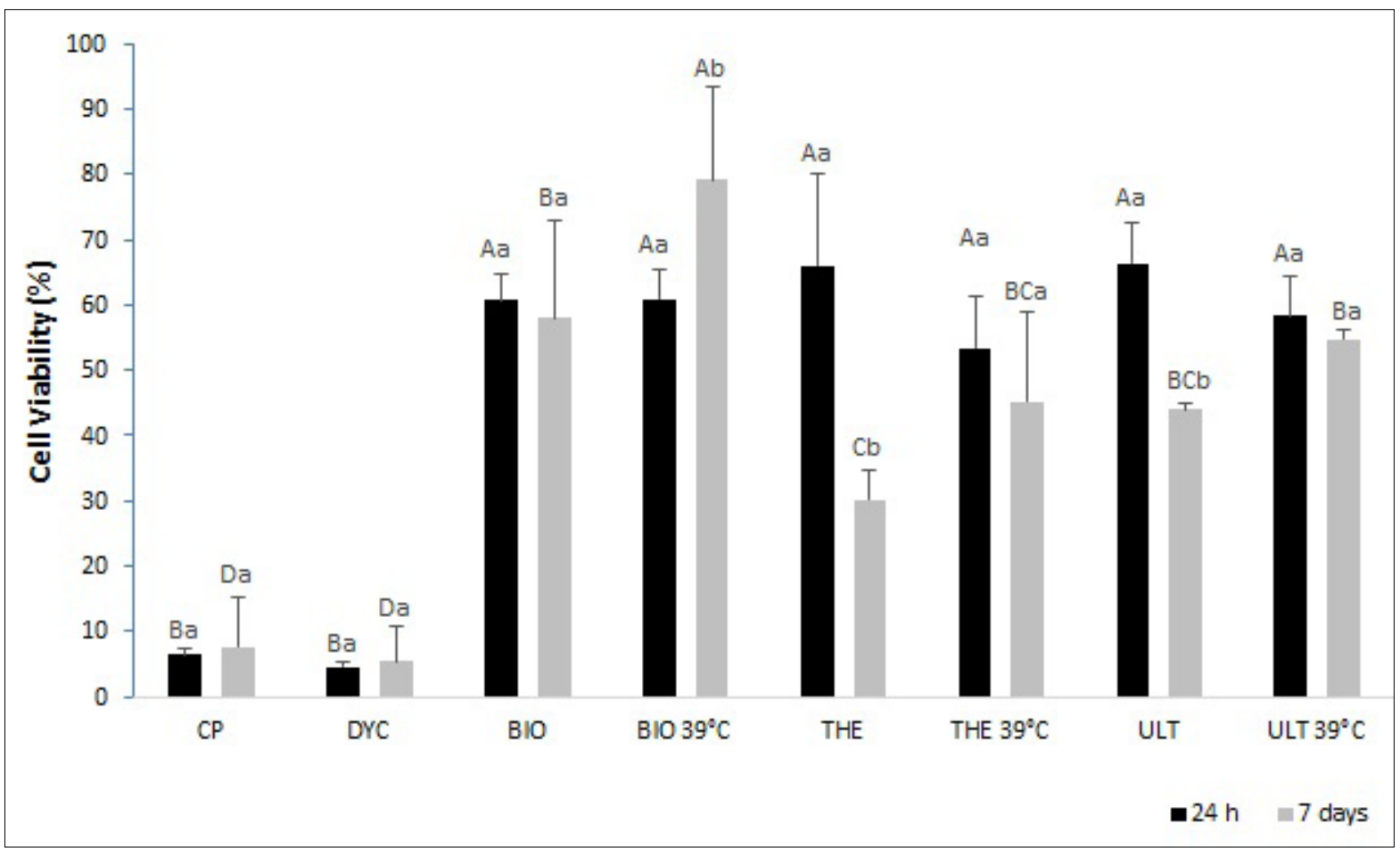

Fig. 1: Percentage of cell viability of experimental and control groups at 24 hours and 7 days. Different capital letters indicate difference between the experimental groups and different lowercase letters indicate difference in the analysis at 24 hours and 7 days.

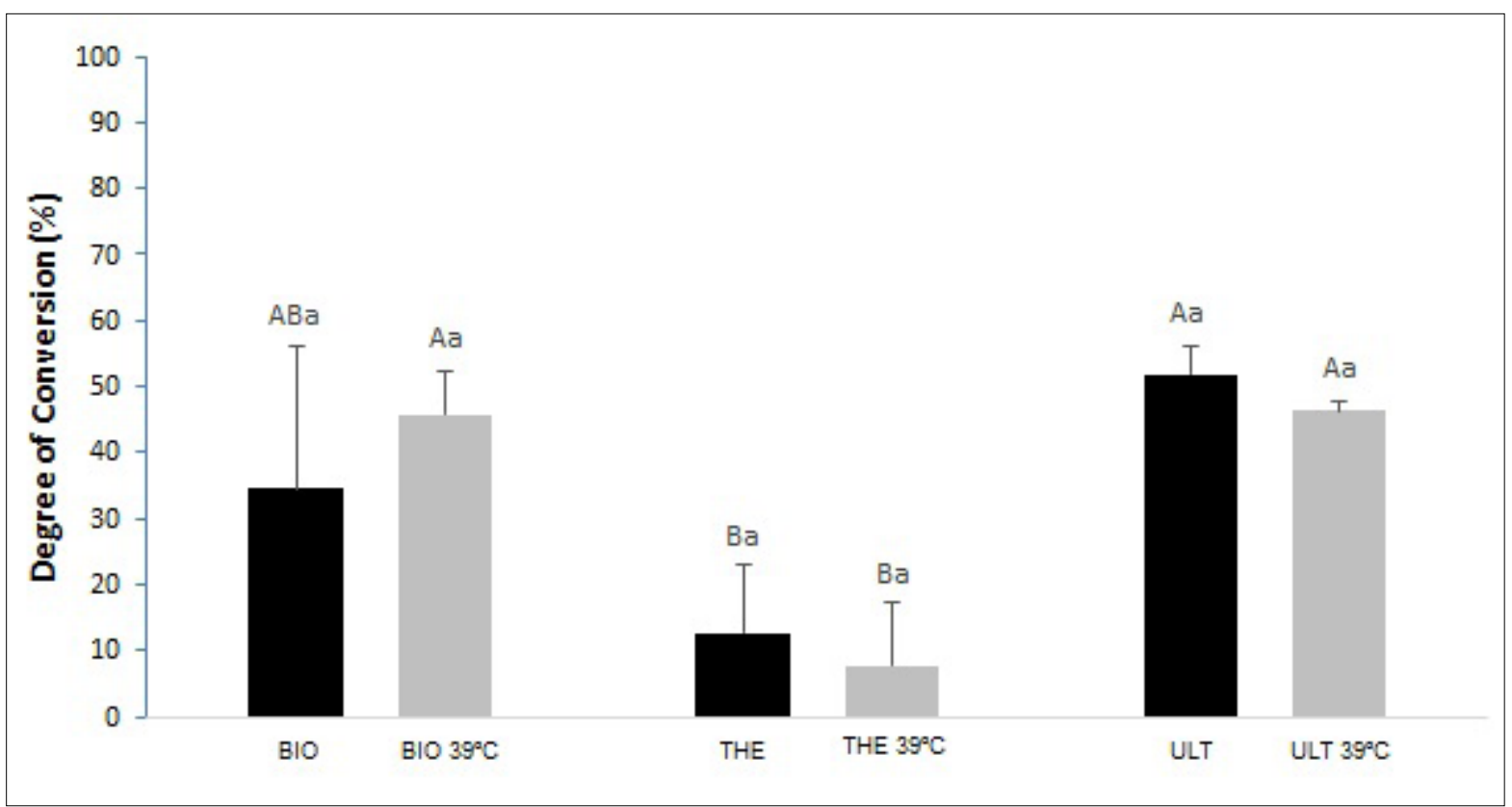

Fig. 2: Percentage of the degree of conversion of the groups at room temperature and preheated to $39{ }^{\circ} \mathrm{C}$. Different capital letters indicate difference between materials and different lowercase letters indicate difference between groups at room temperature and preheated to $39^{\circ} \mathrm{C}$. 
significant loss between $24 \mathrm{~h}$ and 7 days. Ultra-Blend plus ${ }^{\circledR}$ also lost significant mass over the same time. In contrast, Biocal ${ }^{\circledR}$ lost significantly less mass, with no statistical difference from TheraCal ${ }^{\circledR}$ LC at 7 days. Heat treatment had no influence on the mass loss of the materials. Table 2 also shows the $\mathrm{pH}$ variation of the samples analyzed at $24 \mathrm{~h}$ and 7 days. The medium was alkalized for all materials, with DYC and THE $39^{\circ}$ being significantly the most alkaline.

\section{DISCUSSION}

Resin-modified calcium hydroxide or calcium silicate cements are promising dental products for pulp protection ${ }^{7}$. However, it is believed that the release of unpolymerized monomers has great impact on cytotoxicity in pulp cells by both direct and indirect contact, by diffusion of the monomers through the transdental route to the pulp tissue $\mathrm{e}^{12,13,18}$. In addition to decreasing cell viability, this causes the release of pro-inflammatory cytokines and recruitment of inflammatory cells, thus compromising the regenerative process ${ }^{19}$.

Considering that these materials are used in close proximity to the pulp, they should have the ability to protect it in addition to having a high degree of conversion to reduce the possibility of release and diffusion of monomers that can cause pulp damage ${ }^{20}$. However, the degree of conversion was found to be lower than expected for all materials, with half or less than half of the monomers converted into polymers, even when the photoactivation time employed was double that recommended by the manufacturer. The results of the present study differ from the study by Soares et al. ${ }^{21}$ where ULT conversion was close to $90 \%$ and the BIO showed a significantly lower DC than all other leveling materials, close to $75 \%$.

According to some authors ${ }^{22.23}$, the release of unpolymerized monomers from resin composites is greatest during the first $24 \mathrm{~h}$. However, there is a continuous release over time at a reduced rate, due to hydrolysis and degradation of resin-based materials ${ }^{22-26}$. It is believed that the longer the extraction time, the greater will be the amount of unconverted monomers leached from the resin matrix into the extraction medium. Arias-Moliz et $a l .{ }^{27}$ reported that over time, some cements showed an increase in cytotoxicity, and THE became more cytotoxic in 7 days. This is in agreement with our study and may be related to its low percentage of DC. Thus, we noticed that all the tested materials increased the cytotoxicity of the analysis from 24 hours to 7 days, except the $\mathrm{BIO} 39^{\circ} \mathrm{C}$, suggesting that the increase in temperature may have caused greater conversion of the monomers, resulting in an improvement in the biological properties of the product. This relates to our findings that the $\mathrm{BIO}$ $39{ }^{\circ} \mathrm{C}$ achieved a higher degree of conversion when heated than when only photoactivated, even though the difference was not statistically significant. In the 7-day analysis, $\mathrm{BIO} 39^{\circ} \mathrm{C}$ showed no statistical difference when it was only photoactivated, but it showed less cytotoxicity than the other materials tested.

Exposing materials to high temperatures - within a degree biologically compatible with the pulp - has significant effects on their polymerization, increasing the $\mathrm{DC}^{28,29}$ and consequently decreasing their cytotoxicity, as demonstrated by Klein-Júnior et al. ${ }^{12}$, who reported a reduction in cytotoxicity at $24 \mathrm{~h}$ and at 7 days in self-adhesive resin cements

Table 2. Solubility and $\mathrm{pH}$ in the experimental groups according to time.

\begin{tabular}{c|c|c|c|c}
\hline & \multicolumn{2}{|c}{ Weight loss (\%) } & \multicolumn{2}{c}{ pH } \\
\hline DYC & 24 hours & 7 days & 24 hours & 7 days \\
\hline BIO & $2.98 \pm 0.16 \mathrm{BCb}$ & $17.68 \pm 5.39 \mathrm{Aa}$ & $10.62 \pm 0.09 \mathrm{Ab}$ & $11.77 \pm 0.02 \mathrm{Aa}$ \\
\hline $\mathrm{BIO} 39^{\circ} \mathrm{C}$ & $0.13 \pm 0.13 \mathrm{Ca}$ & $0.52 \pm 0.78 \mathrm{Ca}$ & $7.40 \pm 0.42 \mathrm{Cb}$ & $10.11 \pm 0.01 \mathrm{Ca}$ \\
\hline THE & $0.04 \pm 0.07 \mathrm{Ca}$ & $0.13 \pm 0.18 \mathrm{Ca}$ & $7.62 \pm 0.22 \mathrm{BCb}$ & $9.79 \pm 0.18 \mathrm{Ca}$ \\
\hline THE 39॰ $\mathrm{C}$ & $2.27 \pm 0.16 \mathrm{BCa}$ & $2.29 \pm 1.15 \mathrm{Ca}$ & $8.08 \pm 0.02 \mathrm{BCb}$ & $10.98 \pm 0.29 \mathrm{Ba}$ \\
\hline ULT & $2.46 \pm 1.32 \mathrm{BCa}$ & $1.31 \pm 1.64 \mathrm{Ca}$ & $10.88 \pm 0.13 \mathrm{Aa}$ & $11.02 \pm 0.04 \mathrm{Aa}$ \\
\hline \\
ULT 39 ${ }^{\circ} \mathrm{C}$
\end{tabular}


heated to $60{ }^{\circ} \mathrm{C}$. It is believed that heating promotes greater molecular mobility, increasing the frequency of collision of reactive species and postponing the spread of controlled diffusion (auto deceleration), thus resulting in a highly reticulated network of polymers, and presenting a better conversion of monomers ${ }^{29}$.

In contrast, we did not have significant results with preheating, in agreement with Fróes-Salgado et $a l .^{30}$, who reported that pre-heating composite resin did not change its degree of conversion, although it provided better marginal adaptation to the cavity walls. In addition to the temperature of the material being slightly below that supplied by the heating unit, there is a $50 \%$ drop in temperature 2 min after the material is removed from the heating unit ${ }^{29}$. The time possibly elapsed between the removal of material from the device and its photoactivation may have influenced the DC of the material. Another hypothesis would be that the temperature of $39^{\circ} \mathrm{C}$ is not sufficient to promote a significant increase in monomer conversion.

The DC results for the analyzed materials were relatively low, considering the average value of composites is about $70 \%{ }^{7}$. As previously reported by other authors, heat should have improved the DC of these materials ${ }^{11}$. Again, the question of the calcium hydroxide component and its solidity, which becomes a barrier to the mobility of monomers, is raised. It is important to understand that the chemical components of calcium hydroxide, radiopacifiers and derivatives may hinder the conversion of these monomers and prevent heat from further improving this conversion.

Both the chemical composition of the resinous material and the percentage of conversion of monomers in dental materials are considered as a potential cause of cytotoxicity ${ }^{25}$. In a previous study, Deb et al. ${ }^{31}$ showed that preheating at $60{ }^{\circ} \mathrm{C}$ had no effect on cytotoxicity, attributing the different levels of cytotoxicity of the materials to their compositions. The monomers present in resin composites and adhesive systems (e.g., BisGMA, UDMA, TEGDMA, HEMA) have already been shown to have cytotoxic effects in direct contact with fibroblasts and can be leached when the DC is not fully attained ${ }^{9}$. Compounds such as bisphenol glycidyl methacrylate (BisGMA), urethane dimethacrylate (UDMA) and camphorquinone can induce major cell damage ${ }^{32}$. In 2003, Chen et $a l .{ }^{33}$ showed that the BisGMA monomer is the one with the highest cytotoxicity, followed mainly by the UDMA, TEGDMA and HEMA monomers, and verified that interactions between these monomers enhance the cytotoxicity of each one. In the study by Schwengberg et al. ${ }^{32}$, BisGMA exposure resulted in a $50 \%$ decrease in cells, and in the study by Ratanasathien et al..$^{34}$, the UDMA proved to be less cytotoxic than the BisGma after 24 hours and 72 hours of exposure, which may explain the cytotoxic effect found for TheraCal® $\mathrm{LC}$ in the present study. Lee et al. ${ }^{35}$ attributed to the BisGMA found in this material an extensive pulp inflammatory response with a $75 \%$ decrease in cell viability. Similarly, Nilsen et al. ${ }^{36}$ reported a higher concentration of camphorquinone in this material than in other protective materials based on resin.

There are several previous studies on the cytotoxicity of pulp protection materials ${ }^{37,38}$, with the Dycal ${ }^{\circledR}$ showing the greatest cytotoxic effects, even when compared to pulp protection cements. Hirschman et $a l .{ }^{37}$ reported that the cytotoxic effect of Dycal ${ }^{\circledR}$ was greater than that of Ultra-Blend ${ }^{\circledR}$ plus, in agreement with our results. When testing light-cured calciumbased cements, we found a mild and moderate degree of cell cytotoxic reactivity according to the ISO 10993-5: $2009^{17}$ standards, and in terms of biocompatibility they are superior to Dycal ${ }^{\circledR}$, which caused severe cell cytotoxicity.

Even with high initial cytotoxicity, the alkaline medium is important to promote cell differentiation, inducing the formation of secondary dentin, as well as the formation of the mineralized barrier in cases of pulp exposure ${ }^{38}$. On the other hand, LuczajCepowicz et al. ${ }^{39}$ reported that alkaline $\mathrm{pH}$ most likely does not affect the viability of cells in culture. In the present study, Dycal ${ }^{\circledR}$ had the most alkaline $\mathrm{pH}$, the greatest solubility in the 7-day analysis and the greatest toxic effect on cells in culture.

The solubility of the material has an antagonistic character. There is a need for a certain solubilization of calcium ions for the alkalization of the medium to occur and, consequently, tissue repair ${ }^{9}$. However, when this loss of mass is very significant, an empty space remains between the mineralized tissue and the restorative material. Thus, there is a need to achieve a balance between being soluble enough to have a therapeutic effect on the pulp tissue and not compromising the restorative procedure mechanically ${ }^{40}$. 
In conclusion, light-cured calcium-based cements have low DC, mild to moderate cytotoxicity and varying solubility. Preheating the material showed no effect on DC, solubility or cytotoxicity, except for

\section{FUNDING}

None
BIO $39^{\circ} \mathrm{C}$ at 7 days. Chemically activated calcium hydroxide cement was more soluble and cytotoxic than polymerizable materials.

\section{CORRESPONDENCE}

Dr. Roberto Zimmer

Universidade Luterana do Brasil

Departamento de Dentística

Av. Farroupilha, 8001 - Prédio 59

Canoas, RS, Brasil

beto.zimmer@hotmail.com

stream reduces cytotoxicity of lightcured calcium hydroxide based cements. J Clin Exp Dent 2020; 12:215-219.

14. International Organization for Standardization. ISO 1099312: Biological Evaluation of Medical Devices. Part 12: Sample Preparation and Reference Materials. Geneva: International Organization for Standardization; 2002.

15. Portella FF, Collares FM, Santos LA, Santos BP, Camassola M, Leitune VC, Samuel SMW. Glycerol salicylate-based containing $\alpha$-tricalcium phosphate as a bioactive root canal sealer. J Biomed Mater Res B Appl Biomater 2015; 103:1663-1669.

16. Collares FM, Portella FF, Leitune VC, Samuel SMW. Discrepancies in degree of conversion measurements by FTIR. Braz Oral Res 2013; 27:453-454.

17. International Organization for Standardization. ISO 109935:2009 (E). Biological evaluation of medical devices. Part 5: Tests for in vitro cytotoxicity. 3th ed. Genebra: International Standard Organization; 2009.

18. Leite MLAS, De Souza Costa CA, Duarte RM, Andrade AKM, Soares DG. Bond strength and cytotoxicity of a universal adhesive according to the hybridization strategies to dentin. Braz Dent J 2018; 29:68-75.

19. Giraud T, Jeanneau C, Rombouts C, Bakhtiar H, Laurent $\mathrm{P}$, About I. Pulp capping materials modulate the balance between inflammation and regeneration. Dent Mater 2019; 35:24-35.

20. Salehi S, Gwinner F, Mitchell JC, Pfeifer C, Ferracane JL. Cytotoxicity of resin composites containing bioactive glass fillers Dent Mater 2015; 31:195-203.

21. Soares CJ, Ferreira MS, Bicalho AA, de Paula Rodrigues M, Braga S, Versluis A. Effect of light activation of pulp-capping materials and resin composite on dentin deformation and the pulp temperature change. Oper Dent 2018; 43:71-80.

22. Issa Y, Watts DC, Brunton PA, Waters CM, Duxbury AJ. Resin composite monomers after MTT and LDH activity of human gingival fibroblasts in vitro. Dent Mater 2004; 20:12-20.

23. Moharamzadeh K, Van Noort R, Brook IM, Scutt AM. HPLC analysis of components released from dental composites with different resin compositions using different extraction media. J Mater Sci Mater Med 2007; 18:133-137.

24. Hebling J, Lessa FC, Nogueira I, Carvalho RM, Costa CA. Cytotoxicity of resin-based light-cured liners. Am J Dent 2009; 22:137-142. 
25. Ergun G, Egilmez F, Yilmaz S. Effect or reduced exposure time on the cytotoxicity of resin luting cements cured by high-power led. J Appl Oral Sci 2011; 19:286-292.

26. Goldberg M. In vitro and in vivo studies on the toxicity of dental resin components: a review. Clin Oral Investig 2008; 12:1-8.

27. Arias-Moliz MT, Farrugia C, Lung CYK, Wismayer PS, Camilleri J. Antimicrobial and biological activity of leachate from light curable pulp capping materials. J Dent 2017; 64:45-51.

28. Trujillo M, Newman SM, Stanbury JW. Use of near-IR to monitor the influence of external heating on dental composite photopolymerization. Dent Mater 2004; 20:766-777.

29. Daronch M, Rueggeberg FA, De Goes MF, Giudici R. Polymerization kinetics of pre-heated composite. J Dent Res 2008; 85:38-43.

30. Fróes-Salgado NR, Silva LM, Kawano Y, Francci C, Reis A, Loguercio AD. Composite pre-heating: effects on marginal adaptation, degree of conversion and mechanical properties. Dent Mater 2010; 26:908-914.

31. Deb S, Di Silvio L, Mackler HE, Millar BJ. Pre-warming of dental composites. Dent Mater 2011; 27:51-59.

32. Schwengberg S, Bohlen H, Kleinsasser N, Kehe K, et al. In vitro embryotoxicity assessment with dental restorative materials. J Dent 2005; 33:49-55.

33. Chen RS, Liu CC, Tseng WY, Jeng JH, Lin CP. Cytotoxicity of three dentin bonding agents on human dental pulp cells. J Dent 2003; 31:223-229.
34. Ratanasathien S, Wataha JC, Hanks CT, Dennison JB. Cytotoxic interactive effects of dentin bonding components on mouse fibroblasts. J Dent Res 1995; 74:1602-1606.

35. Lee MJ, Kim MJ, Kwon JS, Lee SB, Kim KM. Cytotoxicity of light-cured dental materials according to different sample preparation methods. Materials 2017; 10:288. doi: 10.3390/ ma10030288.

36. Nilsen BW, Jensen E, Örtengren U, Michelsen VB. Analysis of organic components in resin-modified pulp capping materials: critical considerations. Eur J Oral Sci 2017; 125:183-194.

37. Hirschman WR, Wheater MA, Bringas JS, Hoen MM. Cytotoxicity comparison of three current direct pulpcapping agents with a new bioceramic root repair putty. J Endod 2012; 38:385-388.

38. Poggio C, Ceci M, Dagna A, Beltrami R, Colombo M, Chiesa M. In vitro cytotoxicity evaluation of different pulp capping materials: a comparative study. Arh Hig Rada Toksikol 2015; 66:181-188.

39. Luczaj-Cepowicz E, Marczuk-Kolada G, Pawinska M, Obidzinska M, Holownia A. Evaluation of cytotoxicity and $\mathrm{pH}$ changes generated by various dental pulp capping materials - an in vitro study. Folia Histochem Cytobiol 2017; 55:86-93.

40. Portella FF, Collares FM, Santos PD, Sartori C, Wegner E, Leitune VCB, Samuel SMW. Glycerol salicylate-based pulp-capping material containing Portland cement. Braz Dent J 2015; 26:357-362. 